\title{
Islamic Fasting and Thyroid Hormones
}

\author{
Fereidoun Azizi ${ }^{1, *}$ \\ ${ }^{1}$ Endocrine Research Center, Research Institute for Endocrine Sciences, Shahid Beheshti University of Medical Sciences, Tehran, IR Iran \\ ${ }^{*}$ Corresponding author: Fereidoun Azizi, Endocrine Research Center, Research Institute for Endocrine Sciences, Shahid Beheshti University of Medical Sciences, Tehran, IR Iran. Tel: \\ +98-2122409309, E-mail: azizi@endocrine.ac.ir
}

Received: January 2, 2015; Accepted: February 13, 2015

Keywords: Fasting; Hormones; Islam

\section{Introduction}

Alteration in human homeostasis and various parameters of body function during Islamic fasting of Ramadan is completely different from experimental fasting. During Ramadan, the majority of Muslims have two good-sized meals, one immediately after sunset and the other just before dawn. They begin their day of fasting at dawn and continue until sunset. They eat and drink only between sunset and dawn. Since the Islamic calendar is based on a lunar cycle, the Islamic year has 354 days. Therefore, Ramadan moves back 11 days every year and may fall during any of the four seasons, making the duration of daily fasting vary between 11 and 18 hours in the north and in tropical countries. Islamic fasting provides a unique model of intermittent daily fasting from a physiological standpoint. It is also distinct from regular voluntary or experimental fasting in that the faster does not drink during fasting hours. Not only does Ramadan fasting discipline the body to restrain from eating food and drinking water, but a Muslim engages his or her entire body in the physical observance of the Ramadan fast. From foregoing introduction, one may assume that physiological changes occurring during Islamic fasting would differ from those observed during an experimental fast (1).

\section{Thyroid Functions During Ramadan}

It has been shown that in experimental studies fasting is associated with a decline in serum $\mathrm{T} 3$ and a rise in serum rT3. At least part of the reduction in serum T3 is due to a decrease in the peripheral conversion of T4 to T3, mostly in hepatic cells. It has been reported that both serum T3 and rT3 return to prefasting values upon refeeding with a mixed diet (2-4). We have also found that refeeding with a mixed diet or predominantly carbohydrate, diet even though hypocaloric, reverses the changes in serum T3 and rT3 caused by fasting. This finding complements those of other studies that demonstrate the importance of dietary carbohydrate in the modulation of serum T3
(5). A few days of experimental fasting decreases serum TSH concentration, both basal and after administration of thyrotropin-releasing hormone (TRH) (6). Prolonged starvation ( 3 weeks or more), causes no change in basal serum TSH although there may or may not be a decrease in the TSH response to TRH stimulation. Adult patients with protein calorie malnutrition have normal serum TSH values. In anorexia nervosa, basal serum TSH is normal but the TSH response to TRH may be prolonged. Therefore, at least in states of chronic malnutrition, the basal serum TSH does not appear depressed and the response to TRH is not decreased $(5,6)$. No significant alterations in serum concentrations of T4, T3, TSH, and TSH response to of TRH stimulation were found in fasting Muslim males (7). Serum T4 and T3 concentrations may decrease in the last days of Ramadan, in women (8); however, the decline is mainly due to alterations in protein binding, as free thyroid indices remain unchanged $(9,10)$. A small increase in serum T4 in the last days of Ramadan has been reported by some studies, but not substantiated by others (8-11). Serum T3 may decrease in pre-menarche girls without any increase in serum TSH (12).

\section{Thyroid Hormone Replacement}

Levothyroxine is the appropriate medication for thyroid replacement in both primary and secondary hypothyroidism. Levothyroxine is taken usually orally in an empty stomach. The amount of thyroxine absorbed decreases from $80 \%$ in the fasting state to $60 \%$ in the fed state (13). Hence, when taken with food, the absorption of levothyroxine may be incomplete, resulting in more variable and higher serum TSH levels. Therefore, standard recommendation is that levothyroxine should be taken an hour before breakfast on an empty stomach, to prevent interference of its uptake by food or medication (14). While taking levothyroxine in between or with food might not be best, taking it at bedtime is an-

Copyright (C) 2015, Research Institute For Endocrine Sciences and Iran Endocrine Society. This is an open-access article distributed under the terms of the Creative Commons Attribution-NonCommercial 4.0 International License (http://creativecommons.org/licenses/by-nc/4.0/) which permits copy and redistribute the material just in noncommercial usages, provided the original work is properly cited. 
other option, as two studies have shown to have almost the same effect as when taken on an empty stomach (15, 16). In contrast, a randomized crossover trail compared taking levothyroxine in the fasting state, with breakfast, or at bedtime in 65 thyroid cancer, patients with primary hypothyroidism found that fasting state and most beneficial than other times (17). To my experience, taking levothyroxine at bedtime in the Middle-Eastern countries, were dinner is taken between 9-10 pm, is not appropriate. In addition, many foods and medications such as cholestyramine, resin, sucralphate, iron sulphate, calcium preparations, aluminum antacids, raloxifene, activated charcoal, fiber-riched diet, and coffee early in the morning, various soya products and food and herbal remedies may affect levothyroxine absorption $(14,18-23)$.

\section{Thyroid Hormone Replacement During Ramadan}

Studies related to levothyroxine replacement during Islamic fasting are sparse. Karoli et al. (24) studied the impact of bedtime levothyroxine supplementation on serum TSH levels during Ramadan in 47 patients, and found that $29(62 \%)$ had changes $\geq 2 \mathrm{mu} / \mathrm{l}$ of serum TSH by the end of Ramadan. However, they related these changes mainly to the interval between levothyroxine ingestion and the last meal. Since there is no change in disposal of thyroid hormones in the first 24 hours of experimental fasting (5), one may conclude that there should be no need to change the dosage of levothyroxine during Ramadan fasting. However, other factors which change the absorption, metabolism and disposal of thyroid hormones during Ramadan should be carefully considered by both patients and physicians. It is assumed, but not substantiated, that during the month of Ramadan, changes in gastric motility (due to prolonged fasting), interference with heavy meals (gorging), possible alteration in the circadian rhythm and the effect of the deiodinase activity might alter the metabolism of the drug in the body (25). When should a hypothyroid faster take its levothyroxine? Based on the above information, it can be postulated that during Ramadan, the proper administration of levothyroxine is achieved if it is taken either one hour before Iftar (meal taken after sunset) or one hour before Sehur (meal taken before dawn); however, most of the patients find it difficult to wait before Iftare or to wake up that early before Sehur and therefore, either miss the dose or take it with the meal. This problem can be easily managed, if levothyroxine is taken at bedtime, which too has an almost identical lowering effect (if not better) on TSH. However, the patient should not take any food for at least 2 hours before bedtime. In conclusion, changes in serum thyroid hormones and therefore, TSH concentrations during Islamic fasting are minimal and do not alter the health of fasted individuals. In addition, Ramadan fasting per se does not cause any need for change in dosage of levothyroxine in hypothyroid patients, although other factors that require change in levothyroxine dose, in particular the distance between ingestion of medication and last meal and/ or next meal should be considered.

\section{References}

1. Azizi F. Islamic fasting and health. Ann Nutr Metab. 2010; 56(4):273-82.

2. Portnay GI, O'Brian JT, Bush J, Vagenakis AG, Azizi F, Arky RA, et al. The effect of starvation on the concentration and binding of thyroxine and triiodothyronine in serum and on the response to TRH. J Clin Endocrinol Metab. 1974;39(1):191-4

3. Spaulding SW, Chopra IJ, Sherwin RS, Lyall SS. Effect of caloric restriction and dietary composition of serum T3 and reverse T3 in man. J Clin Endocrinol Metab. 1976;42(1):197-200.

4. Carlson HE, Drenick EJ, Chopra IJ, Hershman JM. Alterations in basal and TRH-stimulated serum levels of thyrotropin, prolactin, and thyroid hormones in starved obese men.J Clin Endocrinol Metab. 1977;45(4):707-13.

5. Azizi F. Effect of dietary composition on fasting-induced chang es in serum thyroid hormones and thyrotropin. Metabolism. 1978;27(8):935-42.

6. Vinik AI, Kalk WJ, McLaren H, Hendricks S, Pimstone BL. Fasting blunts the TSH response to synthetic thyrotropin-releasing hormone (TRH). J Clin Endocrinol Metab.1975;40(3):509-11.

7. Azizi F, Rasouli HA, Beheshti S. Evaluation of certain hormones and blood constituents during Islamic fasting month. Med Assoc Thailand. 1986;69:57A.

8. Sulimani RA. The effects of Ramadan fasting on thyroid functions in healthy male subjects. Nutrition Research. 1988;8(5):549-52.

9. Azizi F, Nafarabadi M, Amini M. Serum thyroid hormone concentration in healthy women during month of Ramadan. Emirates Med J. 1994;12:140-3.

10. Ahmadinejad Z, Ziaee V, Rezaee M, Yarmohammadi Y, Shaikh H. The effect of ramadan fasting on thyroid hormone profile: A cohort study. PakJ Biol Sci. 2006;9.

11. Sajid KM, Akhtar M, Malik GQ. Ramadan fasting and thyroid hormone profile.J Pak Med Assoc. 1991;41(9):213-6.

12. Bahrayni SH, Vakili R, Nematy M, Norouzy A, Hashemy I, Ebrahi$\mathrm{mi}$ M. The effect of Ramadan fasting on thyroid hormones in 9-13 years old pre-menarche girls. J Fasting Health. 2013;1:46-52.

13. Fish LH, Schwartz HL, Cavanaugh J, Steffes MW, Bantle JP, Oppenheimer JH. Replacement dose, metabolism, and bioavailability of levothyroxine in the treatment of hypothyroidism. Role of triiodothyronine in pituitary feedback in humans. $N$ Engl J Med. 1987;316(13):764-70.

14. Biondi B, Wartofsky L. Treatment with thyroid hormone. Endocr Rev. 2014;35(3):433-512.

15. Bolk N, Visser TJ, Kalsbeek A, van Domburg RT, Berghout A. Effects of evening vs morning thyroxine ingestion on serum thyroid hormone profiles in hypothyroid patients. Clin Endocrinol (Oxf). 2007;66(1):43-8.

16. Rajput R, Chatterjee S, Rajput M. Can Levothyroxine Be Taken as Evening Dose? Comparative Evaluation of Morning versus Evening Dose of Levothyroxine in Treatment of Hypothyroidism. Thyroid Res. 2011;2011:505239.

17. Bach-Huynh TG, Nayak B, Loh J, Soldin S, Jonklaas J. Timing of levothyroxine administration affects serum thyrotropin concentration. J Clin Endocrinol Metab. 2009;94(10):3905-12.

18. Campbell NR, Hasinoff BB, Stalts H, Rao B, Wong NC. Ferrous sulfate reduces thyroxine efficacy in patients with hypothyroidism. Ann Intern Med.1992;117(12):1010-3.

19. Sherman SI, Tielens ET, Ladenson PW. Sucralfate causes malabsorption of L-thyroxine. Am J Med.1994;96(6):531-5.

20. Singh N, Singh PN, Hershman JM. Effect of calcium carbonate on the absorption of levothyroxine. JAMA. 2000;283(21):2822-5.

21. Siraj ES, Gupta MK, Reddy SS. Raloxifene causing malabsorption of levothyroxine. Arch Intern Med. 2003;163(11):1367-70.

22. Liel Y, Harman-Boehm I, Shany S. Evidence for a clinically impor- 


\section{Azizi F}

tant adverse effect of fiber-enriched diet on the bioavailability of levothyroxine in adult hypothyroid patients. J Clin Endocrinol Metab.1996;81(2):857-9.

23. Benvenga S, Bartolone L, Pappalardo MA, Russo A, Lapa D, Giorgianni $\mathrm{G}$, et al. Altered intestinal absorption of L-thyroxine caused by coffee. Thyroid. 2008;18(3):293-301.
24. Karoli R, Fatima J, Chandra A, Mishra PP. Levothyroxine replacement and Ramadan fasting. Indian J Endocrinol Metab. 2013;17(2):318-9.

25. Raza SA, Ishtiaq O, Unnikrishnan AG, Khan AK, Ahmad J, Ganie MA, et al. Thyroid diseases and Ramadan. Indian J Endocrinol Metab. 2012;16(4):522-4. 